\title{
DENDROCHRONOLOGY AND RADIOCARBON DATING: THE LABORATORY OF TREE-RING RESEARCH CONNECTION
}

\author{
Steven W Leavitt ${ }^{1}$ Bryant Bannister \\ Laboratory of Tree-Ring Research, University of Arizona, Tucson, Arizona 85721, USA.
}

ABSTRACT. The field of dendrochronology had a developmental "head start" of at least several decades relative to the inception of radiocarbon dating in the late 1940s, but that evolution was sufficiently advanced so that unique capabilities of tree-ring science could assure success of the ${ }^{14} \mathrm{C}$ enterprise. The Laboratory of Tree-Ring Research (LTRR) at the University of Arizona played a central role in the cross-pollination of these disciplines by providing the first wood samples of exactly known age for the early testing and establishment of the "Curve of Knowns" by Willard Libby. From the 1950s into the early 1980s, LTRR continued to contribute dated wood samples (bristlecone pine and other wood species) to ${ }^{14} \mathrm{C}$ research and development, including the discovery and characterization of de Vries/Suess "wiggles," calibration of the ${ }^{14} \mathrm{C}$ timescale, and a variety of tests to understand the natural variability of ${ }^{14} \mathrm{C}$ and to refine sample treatment for maximum accuracy. The long and varied relationship of LTRR with ${ }^{14} \mathrm{C}$ initiatives has continued with LTRR contributions to high-resolution studies through the 1990s and systematic efforts now underway that may eventually extend the bristlecone pine chronology back beyond its beginning $8836 \mathrm{yr}$ ago as of 2009 . This relationship has been mutualistic such that a half-century ago the visibility and stature of LTRR and dendrochronology were also elevated through their association with ${ }^{14} \mathrm{C}$-allied "hard sciences."

\section{INTRODUCTION}

Near the dawn of the 20th century, the interest of astronomer Andrew E Douglass in sunspot activity (and its possible relationship with climate) inspired his study of tree rings, leading to an extraordinary body of inquiry and publication for which he would eventually become known as the "Father of Modern Dendrochronology." When he established the University of Arizona Laboratory of TreeRing Research (LTRR) in 1937, a little less than a decade had passed since the field of dendrochronology rose to international prominence with the widely heralded triumph of the absolute dating of archaeological ruins around the US Southwest (Douglass 1929). Only a decade after LTRR's inception, a new field was in it infancy some $2300 \mathrm{~km}$ away. The new field of radiocarbon dating would ultimately also cast its own novel and intense illumination on dating questions in archaeology around the world and then likewise on many other fields. Although unanticipated by the early principals in dendrochronology and ${ }^{14} \mathrm{C}$, their efforts were destined to become intimately intertwined on several fronts in the second half of the 20th century.

At the approximate time of their intersection, one of us (BB) became aware of both of these fields while enrolled in an anthropology course taught by Ralph Linton of Yale University in fall 1947 (Figure 1). Around this time, Willard Libby at the University of Chicago was calling for dated materials to test his novel ${ }^{14} \mathrm{C}$ dating method (Marlowe 1999), and although historical artifacts may have been at the top of his list, tree-ring dated wood from the University of Arizona subsequently provided important samples for the early demonstrations of the accuracy of ${ }^{14} \mathrm{C}$ dating. Shortly thereafter, dated tree rings from LTRR were central to first recognizing the fluctuation ("wiggles") in ${ }^{14} \mathrm{C}$ production, and then to calibrating ${ }^{14} \mathrm{C}$ dates against real time and extending the calibration back thousands of years.

This paper examines the pervasive role of dendrochronology at LTRR in milestone advances in ${ }^{14} \mathrm{C}$ dating, largely related to improving accuracy of the ${ }^{14} \mathrm{C}$ method via contributions to calibration, standards, and studies to understand processes that might influence results. In many cases, LTRR contributions are related to development of the bristlecone pine chronology from the White Mts of Cal-

${ }^{1}$ Corresponding author. Email: sleavitt@1trr.arizona.edu.

(C) 2009 by the Arizona Board of Regents on behalf of the University of Arizona Celebrating 50 Years of Radiocarbon

RADIOCARBON, Vol 51, Nr 1, 2009, p 373-384 


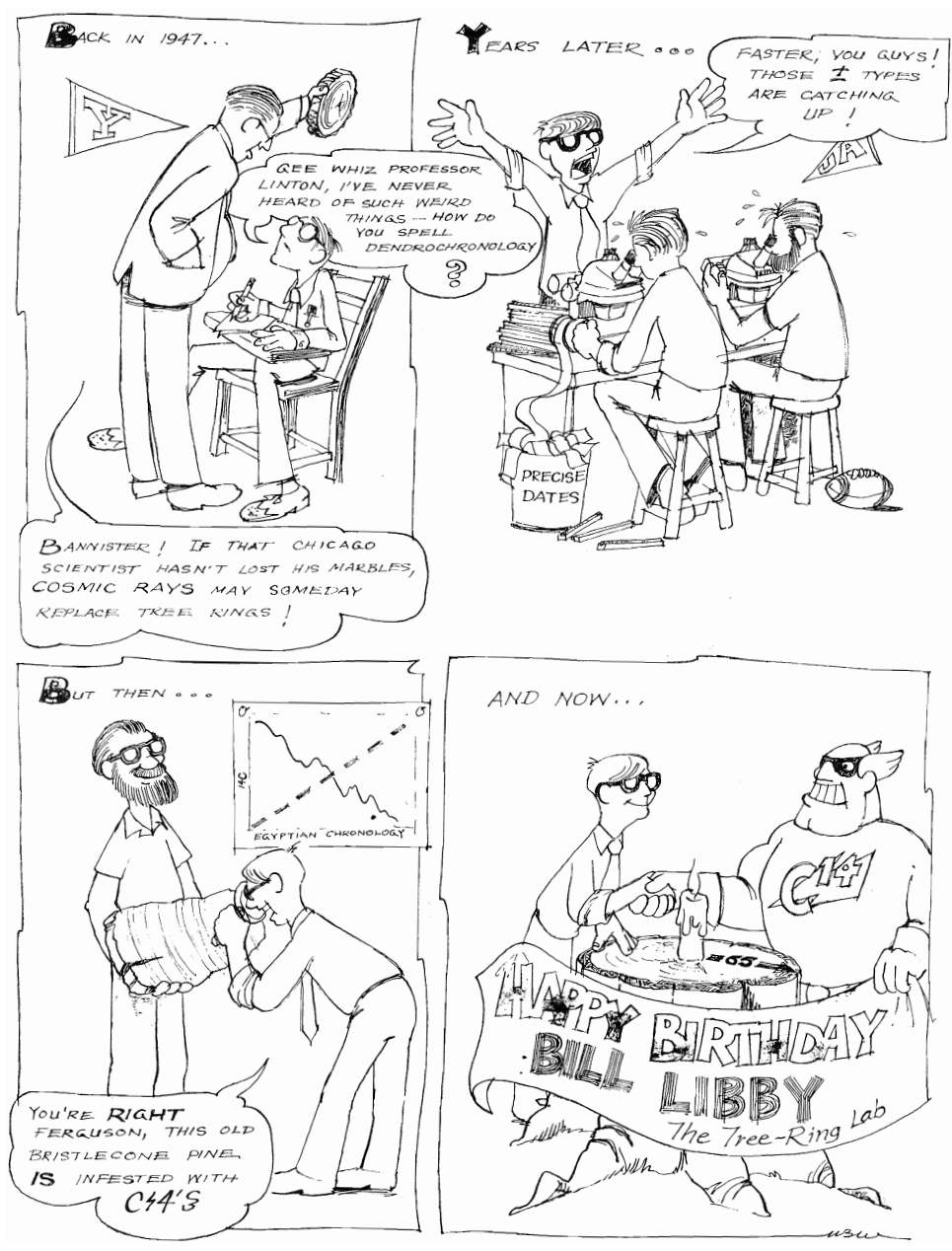

Figure 1 Cartoon presented by the LTRR to Willard Libby on the occasion of his 65th birthday (17 December 1973). The cartoon depicts the history of coauthor Bryant Bannister learning about both dendrochronology and ${ }^{14} \mathrm{C}$ ("cosmic rays") at Yale from Ralph Linton's anthropology course (upper left), tree-ring dating at LTRR when Bannister was director (upper right), C Wesley Ferguson providing wood for ${ }^{14} \mathrm{C}$ calibration (lower left), and a close association of tree rings (Bannister) and ${ }^{14} \mathrm{C}$ (Libby) on his birthday (lower right) [by kind permission of the artist, Wallace B Woolfenden].

ifornia, for which valuable summaries have already been written (cf. Ferguson 1970a; Damon 1987; McGraw 2007). It is particularly with respect to the bristlecone pine chronology that at times the needs of the ${ }^{14} \mathrm{C}$ community were even instrumental in guiding and accelerating some of the related dendrochronology achievements. However, in reality, the supply of dated wood for ${ }^{14} \mathrm{C}$ studies was not solely met with bristlecone pine but also with wood from other species and locations, so we have chosen in this paper to examine more broadly the role of LTRR in the progress of the ${ }^{14} \mathrm{C}$ field.

\section{THE POWER AND ACCURACY OF DENDROCHRONOLOGY}

The field of dendrochronology is based on "crossdating" (matching) of ring patterns of small and wide growth rings among trees to assign absolute calendar ages to each ring with no error (i.e. "den- 
drodating"). Dendrochronology recognizes and accounts for the occasional presence of "false rings" and the occasional local absence of rings ("missing rings"), the frequency of which depends on species and environments in which the trees are growing. Thus, dendrochronology is much more than a simple "ring counting" exercise, which could produce significant errors in dating if the false and missing rings are not recognized and accounted for. For example, Ferguson et al. (1966) reported that in some instances long-lived bristlecone pines might have 5\% or more rings missing along a given radius. At this rate, if simple ring counting was employed, the count would be off by $50 \mathrm{yr}$ or more in a 1000-yr-old tree and $200 \mathrm{yr}$ or more in a 4000-yr-old tree.

Dated chronologies of tree rings have been developed from many species and locations. Among the most remarkable and well known is that of bristlecone pine (Pinus longaeva) in the California White Mountains (Ferguson 1968). The initial development of the chronology and the recognition of bristlecone pine's great antiquity by Edmund Schulman of LTRR were only realized a little over $50 \mathrm{yr}$ ago (Schulman 1954, 1956, 1958). The high elevation, short growing season, lack of stand-replacing forest fires, and cool/dry conditions at $10,000+\mathrm{ft}(3050+\mathrm{m})$ where they grow are conducive to the great ages of individual living trees (up to $5000 \mathrm{yr}$ ) and to preservation of dead material as standing snags and wood lying on the ground, the latter being first used to extend the chronology by LTRR's $\mathrm{C}$ Wesley Ferguson. The chronology has been developed in a progression of steps to a current length of $8836 \mathrm{yr}$ as of AD 2009 (Ferguson 1970b; Ferguson and Graybill 1983; T Harlan, personal communication). Furthermore, wood remnants containing 500-600 rings that predate the beginning of the chronology have been identified by ${ }^{14} \mathrm{C}$ dating and offer the potential of extending this chronology back 10,000 yr or more (Ferguson et al. 1985). Beginning in the 1970 s, the use of ${ }^{14} \mathrm{C}$ ages on remnant wood samples became more common in order to get "ball park" ages to identify the best prospects for chronology extension. Such ${ }^{14} \mathrm{C}$ ages were not used to "force" a specimen into the master treering chronology, but rather to help sort samples by approximate age and serve as a guide for where to begin looking for crossdating. A concerted effort is now underway to catalog all existing samples from the White Mountains site, map their locations, and collect new samples (Hallman et al. 2006).

\section{INITIAL TESTING OF THE RADIOCARBON METHOD}

Among Libby's first tests was Egyptian material with known historical age, but to more fully explore radiocarbon's accuracy, he enlisted the assistance of archaeologists and geologists from their respective professional societies to identify appropriate samples (Libby 1967). The initially reported relationship between historical age and ${ }^{14} \mathrm{C}$ activity (Arnold and Libby 1949), called the "Curve of Knowns," contained 2 samples dendrodated by A E Douglass himself along with 4 other samples dated from historical records (including wood from other sources not dated by dendrochronology). The younger sample was a Douglas-fir (Pseudotsuga menzesii) post (Figure 2) from a pithouse at Broken Flute Cave in the Red Rock Valley of northeastern Arizona whose ring sequence dated from AD 530 to 623, provided by Terah L ("Ted") Smiley of LTRR. The older sample, called "redwood" by Libby but properly termed "giant sequoia" (Sequoiadendron giganteum), was from the "Centennial Tree" (Figure 3) in the Sierra Nevada of California, which contained rings from 1031 to 928 BC as provided by Edmund Schulman. The "Curve of Knowns" was expanded over the years by Libby and colleagues until a much later version (Libby 1961) added another piece of dated wood from LTRR (provenience not specified in that publication) and 7 additional samples dated from written records.

From the full data set, Libby judged the agreement between ${ }^{14} \mathrm{C}$-derived ages and known ages as "satisfactory" (Arnold and Libby 1949; Libby 1961). On closer inspection, Libby (1963) noted "good agreement" between historic dates of Egyptian samples with their ${ }^{14} \mathrm{C}$ dates over the last $4000 \mathrm{yr}$, but 


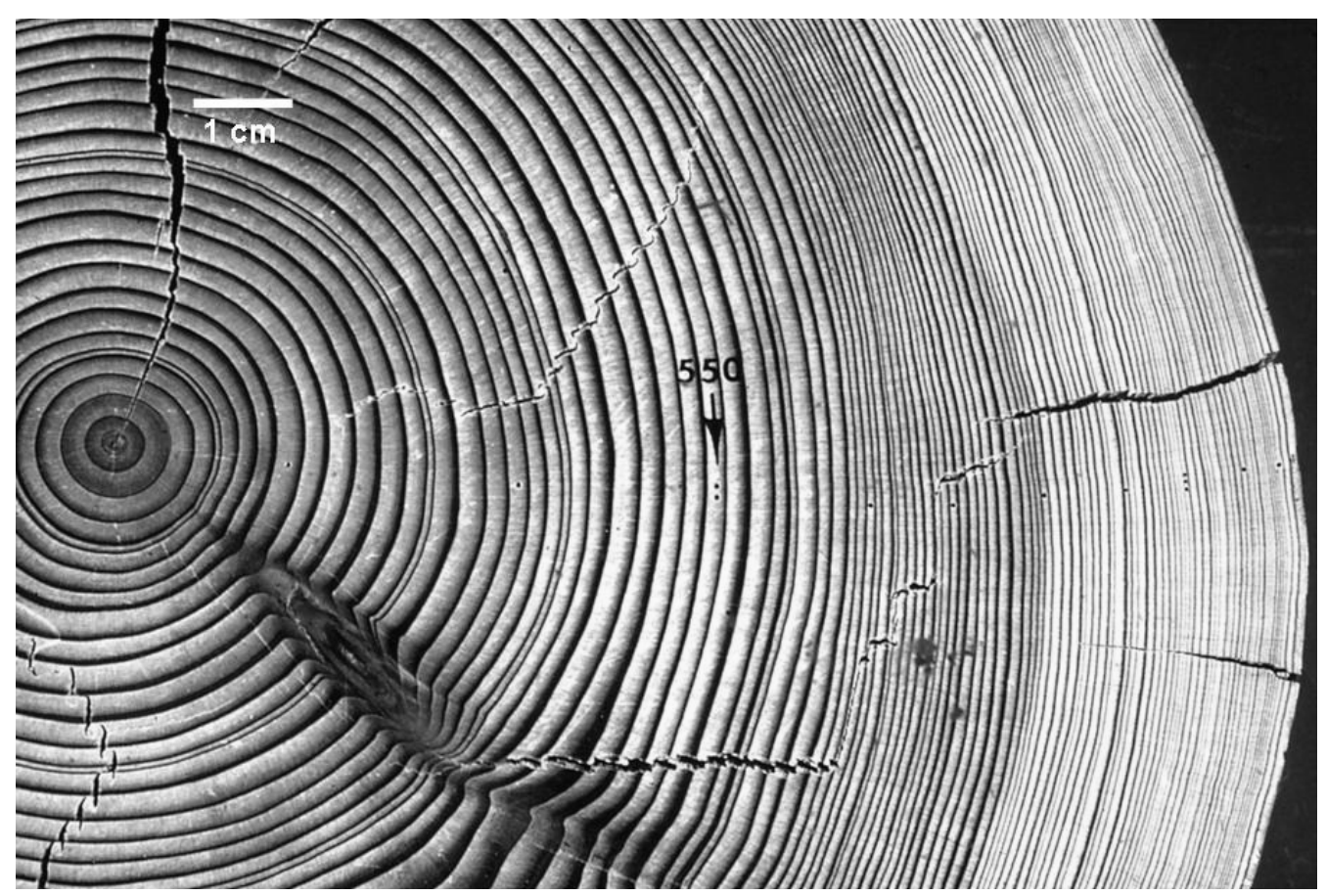

Figure 2 Cross-section of Douglas-fir archaeological beam (sample \#MLK-127, dating to AD 521-623) from Broken Flute Cave, Arizona. Another cross-section (dating to AD 530-623) from the same beam was provided to W Libby from LTRR for one of the first dendrodated points in his "Curve of Knowns."
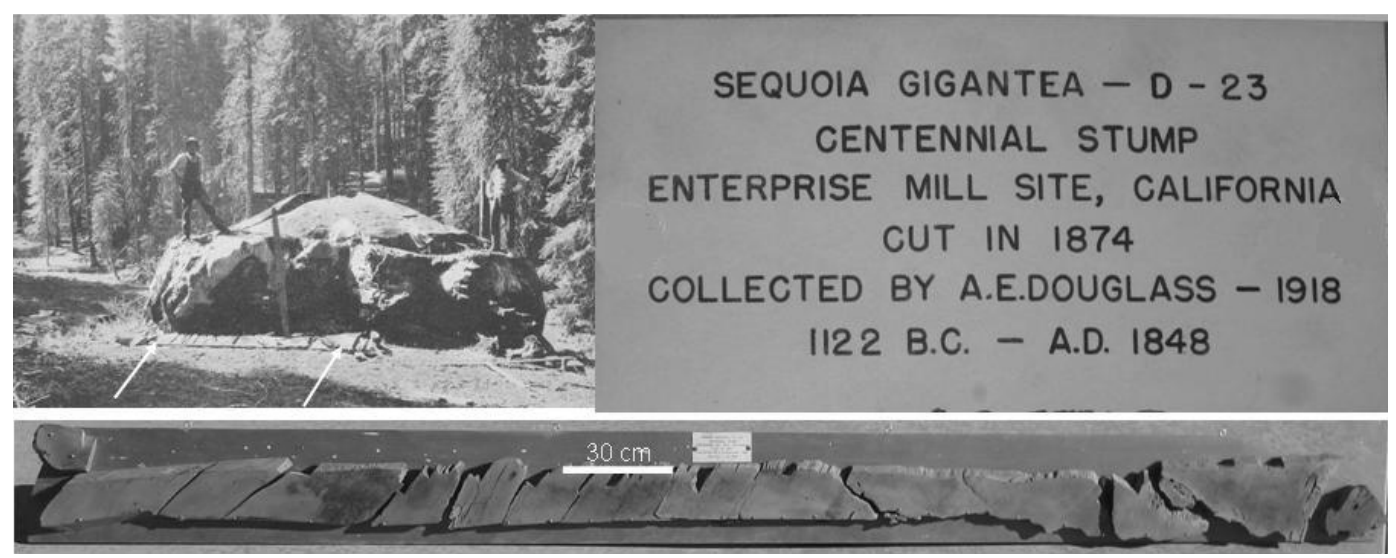

Figure 3 Radial section (bottom) of giant sequoia "Centennial Tree" (sample \#D-23) felled in AD 1874 from which a sample from 1031 to $928 \mathrm{BC}$ was provided by LTRR to W Libby and incorporated as one of the first dendrodated points into his "Curve of Knowns." Upper left is field photo of stump and radial cut sitting on ground (ends indicated with arrows). This sample is now on display in the Laboratory of Tree-Ring Research. [Note that the pieces of wood of the radial section are glued on to a nearly rectangular piece of wood to stabilize them.]

detected deviations of about $3 \%$ between a larger emerging set of dendrodated samples and their ${ }^{14} \mathrm{C}$ dates from ${ }^{14} \mathrm{C}$ labs at Scripps Institution of Oceanography (also referred to as "La Jolla" and UCSan Diego), University of Arizona, and University of Pennsylvania between about 3000 and $3600 \mathrm{yr}$ ago. Libby (1963) cited some recently reported potential "problems" in tree-ring dating (Glock and 
Agerter 1963) related to issues such as multiple growth layers in a single year ("false rings"), in a subtle intimation that possible errors in tree-ring dating could be the source of the discrepancies. However, these potential problems with dendrodating were already well known, and in fact successful dendrochronology identifies these circumstances and corrects for them. In the case of bristlecone pine, Ferguson et al. (1966) further argued that examination of 1000 trees did not even reveal any false rings. Additionally, an independent bristlecone pine chronology from a different site in the White Mountains developed by LTRR's V C LaMarche and T P Harlan (1973) back to 3435 BC demonstrated no errors in the original chronology of Ferguson (1970b).

In further recognition of the need to reduce error in ${ }^{14} \mathrm{C}$ analysis and to improve the certainty of dating, some (e.g. Whitaker et al. 1959) were motivated by the observation of differences in ${ }^{14} \mathrm{C}$ content among coeval wood samples from different geographical locations (Brannon et al. 1957) to investigate local effects such as possible uptake of soil ${ }^{14} \mathrm{C}$-depleted $\mathrm{CO}_{2}$ by leaves (or roots) and assimilation during photosynthesis. To test for possible influence of climate in these differences, Whitaker et al. (1959) analyzed 21 rings (in some cases 2 or more pooled rings where they were individually narrow) over about $200 \mathrm{yr}$ from the "Hitchcock" Douglas-fir tree in southern Arizona (described in greater detail below; see Figure 4) provided by T Smiley. Results were suggestive of higher ${ }^{14} \mathrm{C}$ content in dry years than wet years, but the observation was not statistically significant, nor had any pretreatment been employed to prevent errors from translocation of mobile organic compounds among rings (see "Radiocarbon-Related Tree Physiology and Sample Pretreatment" section below).

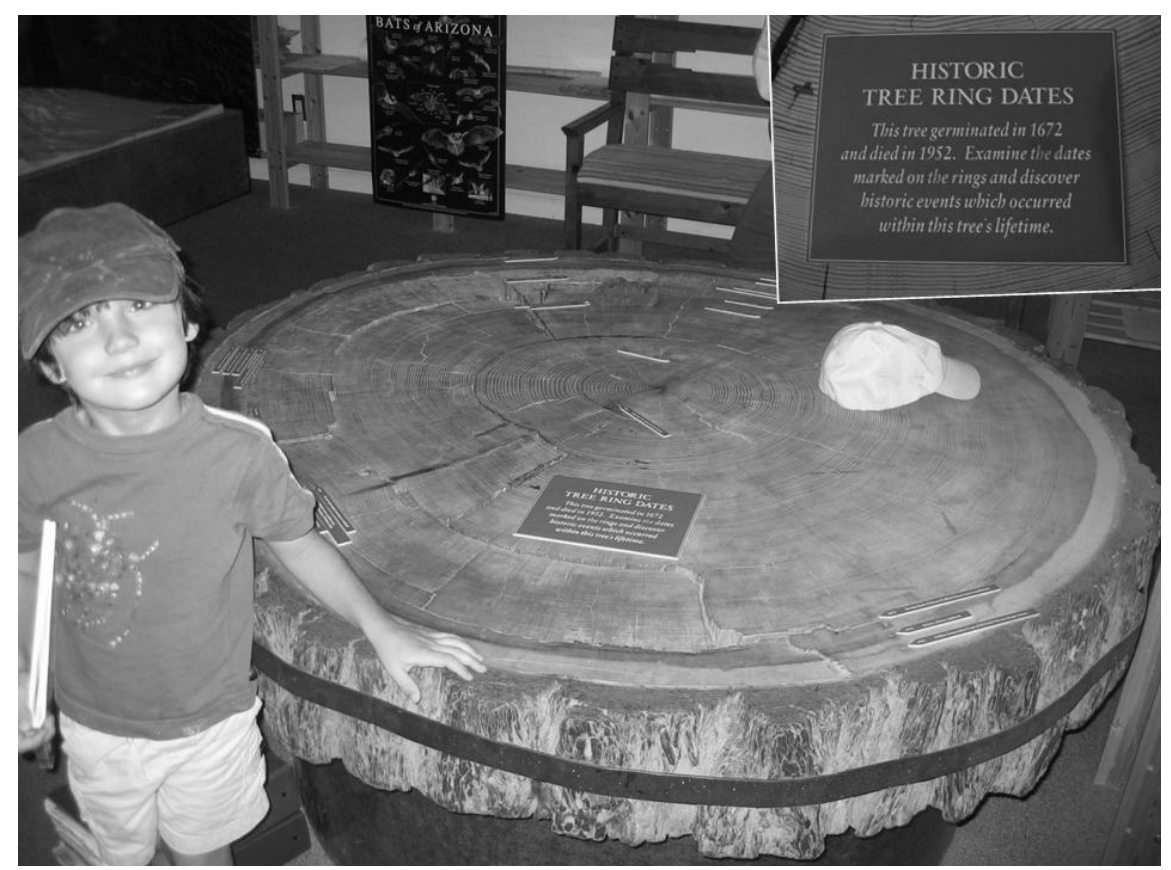

Figure 4 Cross-section of the Hitchcock Tree from the Santa Catalina Mountains near Tucson. This section is on display at the Palisades Ranger Station of the Coronado National Forest, and several other crosssections from this tree of similar size are in storage at the Laboratory of Tree-Ring Research, originally collected by Edmund Schulman. Upper right inset is close-up of the plaque on the surface of the cross-section. Tree rings from this tree played a role in the confirmation and characterization of de Vries/Suess "wiggles" (also related to calibration issues), studies of geographical variation in ${ }^{14} \mathrm{C}$ concentration, and they were prepared as an international standard to calibrate a new primary sucrose standard to replace the original oxalic acid standard in the 1970s. 


\section{IDENTIFICATION OF WIGGLES IN RADIOCARBON PRODUCTION}

The detection of discrepancies in ${ }^{14} \mathrm{C}$ and historical or dendrodates by Libby, as small as they might be, provided impetus for looking at the relationship in greater detail. To this end, de Vries (1958, 1959) analyzed ${ }^{14} \mathrm{C}$ content of 3 tree-ring series, including one LTRR dendrodated Douglas-fir tree from Mesa Verde, Colorado, provided by E Schulman and dating back to about AD 1700. The analysis detected 1-2\% fluctuations in ${ }^{14} \mathrm{C}$ activity, known as "wiggles" or "secular variations," with centennial-scale periodicity (Damon 1987), and a pattern of declining ${ }^{14} \mathrm{C}$ activity over the last $100 \mathrm{yr}$ or so related to dilution by carbon dioxide $\left(\mathrm{CO}_{2}\right)$ from ${ }^{14} \mathrm{C}$-free fossil fuels.

Suess (1955) had previously identified this downward post-1800 trend in ${ }^{14} \mathrm{C}$ using tree rings from wood that was neither dendrodated nor provided by LTRR, and this dilution by ${ }^{14} \mathrm{C}$-depleted fossil fuels has come to be known as the Suess effect. Suess (1965) later verified de Vries' original observations of ${ }^{14} \mathrm{C}$ wiggles (the "de Vries effect") using dendrodated giant sequoia and archaeological Douglas-fir and ponderosa pine (Pinus ponderosa) samples provided from LTRR by B Bannister and M A Stokes. In 1955, Dorn et al. (1962) had begun ${ }^{14} \mathrm{C}$ analysis of 2 dendrodated giant sequoia specimens of 3000 and $2000 \mathrm{yr}$ in length, as provided from LTRR by Smiley, to examine the stability of ${ }^{14} \mathrm{C}$ production and to estimate the half-life of ${ }^{14} \mathrm{C}$ decay. Their coarse-resolution measurements indicated some of these wiggles, which they thought "may limit the ultimate usefulness of the C14-dating method for obtaining absolute ages," but they could not reasonably estimate half-life as originally intended (Dorn et al. 1962). Stuiver (1965) independently verified the de Vries wiggles with high-resolution 17th and 18th century LTRR dendrodated Douglas-fir wood from the Hitchcock tree near Tucson, provided by Stokes and Smiley. Consequently, these fluctuations have been termed both de Vries effects and "Suess wiggles" (Taylor 1987). Timing of the de Vries' wiggles is suggestive of a link with solar activity that modulates ${ }^{14} \mathrm{C}$ production (Stuiver 1961; Damon et al. 1978; Damon and Peristykh 2000).

After their discovery, the geographical variability of these wiggles was of interest, and again tree rings proved to be the ideal natural material with which to test this possibility. Lerman et al. (1970) examined new and published ${ }^{14} \mathrm{C}$ measurements from 22 sites around the world to address this question. The samples included LTRR-dated wood from Colorado (Mesa Verde National Park wood from Schulman, already analyzed by others), California (Hoist Ridge giant sequoia wood from Sequoia National Forest from Stokes, analyzed for this study), and Arizona (Hitchcock Douglas-fir tree by Smiley, already analyzed by others). Similarity in the amplitude of wiggles as well as their synchronicity around the world was established, but a latitudinal gradient in ${ }^{14} \mathrm{C}$ content was also observed, which the authors felt could be modeled as related to location of primary tropospheric ${ }^{14} \mathrm{C}$ inputs and removal by marine carbon sinks. Cain and Suess (1976) compared the ${ }^{14} \mathrm{C}$ activity in $140-$ and 150-yr ring series of 2300-yr old samples, respectively derived from bristlecone pine provided by Ferguson and from German oak provided by Bernd Becker (University of Hohenheim), to determine if in situ cosmic-ray production of ${ }^{14} \mathrm{C}$ might have occurred at the high-elevation bristlecone pine site. They found no difference between activities in the oak and bristlecone series, thus inferring any ${ }^{14} \mathrm{C}$ variation associated with in situ cosmic ray ${ }^{14} \mathrm{C}$ production in wood to be negligible.

Wiggles have turned out to be a prominent feature of the full ${ }^{14} \mathrm{C}$ record and have provided ${ }^{14} \mathrm{C}$ reference patterns that have been helpful in assigning more accurate ages to wood that has not or cannot be dendrodated. This is done by measuring the ${ }^{14} \mathrm{C}$ content in a sequence of ring groups (for example, 10 -yr ring groups) in the undated sample, and then matching the resulting series of ${ }^{14} \mathrm{C}$ ages with the master ${ }^{14} \mathrm{C}$ calibration record (see next section), in a process known as "wiggle-matching." This method has the potential to produce dates more accurate than a single ${ }^{14} \mathrm{C}$ date, and in fact, an LTRR-related study was one of the earliest applications of wiggle-matching. Ferguson et al. (1966) 
used ${ }^{14} \mathrm{C}$ activity in wood from a bristlecone pine series in 10- to 50-yr ring groups as a reference against which to match a ${ }^{14} \mathrm{C}$ sequence of oak timbers from settlements of Swiss lake dwellers around $4000 \mathrm{BC}$.

\section{THE RADIOCARBON CALIBRATION EFFORT}

The presence of "wiggles" in the ${ }^{14} \mathrm{C}$ activity record was symptomatic of the need for systematic calibration of the ${ }^{14} \mathrm{C}$ timescale (Damon and Peristykh 2000) in order to achieve the most accurate ${ }^{14} \mathrm{C}$ dating. Tree rings offered the best resource of absolutely dated organic matter that could be used to establish a continuous calibration, and this effort effectively began in the 1960s with bristlecone pine (Figure 5) and continues today with other species. By the early 1960s, Libby (1963) had already expanded his comparison of ${ }^{14} \mathrm{C}$ versus calendar dates by means of additional ${ }^{14} \mathrm{C}$ measurements on LTRR dendrodated Sequoia, Douglas-fir, and bristlecone pine wood going back thousands of years as analyzed by 4 US and 3 European laboratories.

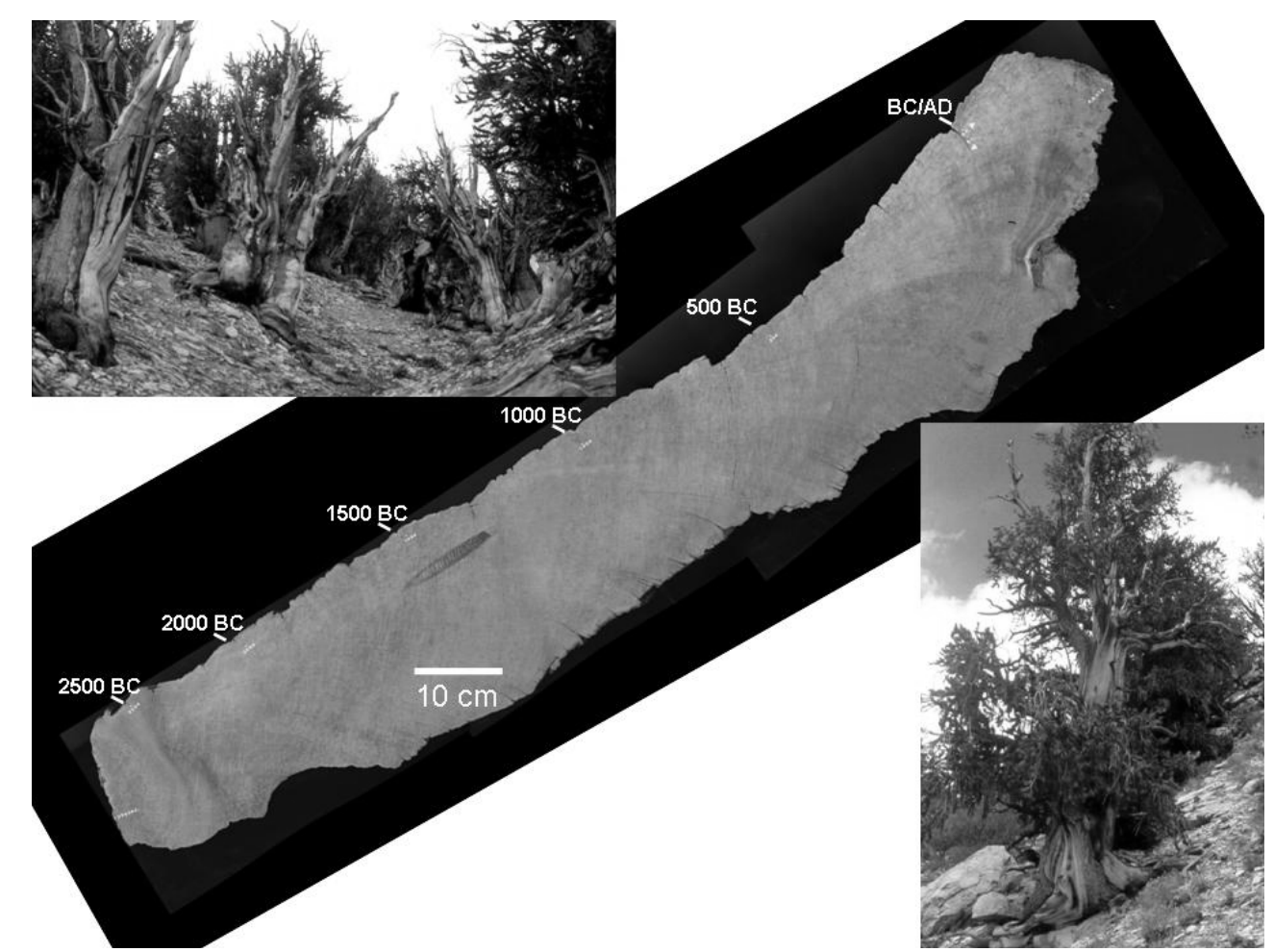

Figure 5 Bristlecone pine cross-section containing 2700 rings (2963 BC to AD 279), and field photos of bristlecone pines (from the Methuselah Walk area in the California White Mountains) showing circumstances of growth (bark and leaves) on one side of the tree known as "strip-bark."

The LTRR bristlecone pine project was an independent effort in chronology building that started with one of the early NSF grants to the University of Arizona in January 1956 (Schulman as principal investigator), titled "Millennium-Long Tree-Ring Histories of Climatic Change." In a letter dated 5 June 1958, to Dr Carl L Hubbs of Scripps Institution where Hans Suess established his ${ }^{14} \mathrm{C}$ laboratory, Bannister proposed providing the ${ }^{14} \mathrm{C}$ community with bristlecone pine rings in blocks of 10 to 20 rings from $4000 \mathrm{yr}$ ago to the present as "a standardized control for the correlation of C-14 dates," 
i.e. effectively a plan for systematic and high-resolution calibration of the ${ }^{14} \mathrm{C}$ timescale. This letter followed the premature death of Schulman, an event that set back the bristlecone dating effort. Subsequently, early requests for wood from LTRR resulted in contributions to Scripps Institution, University of Pennsylvania, and University of Arizona, with whom LTRR had good working relationships with their respective directors, Hans Suess, Elizabeth Ralph, and Paul Damon. In fact, the 3 laboratories generally received identical samples of wood on which to measure ${ }^{14} \mathrm{C}$ content following the launch of collaboration in 1961-64 with Ferguson, who took over the bristlecone initiative.

According to Klein et al. (1982), about $15{ }^{14} \mathrm{C}$ calibrations had been published in the 1970 s, including several from the 3 laboratories above. The "Workshop on the Calibration of the Radiocarbon Dating Time Scale" was held in Tucson from January 29 to February 2 in 1979 in order to achieve a single, consensus ${ }^{14} \mathrm{C}$ calibration based on dendrodated tree-ring samples measured by National Science Foundation-funded US ${ }^{14} \mathrm{C}$ laboratories (Damon et al. 1980). To that end, LTRR-dated bristlecone (1132 samples) and giant sequoia (22 samples) wood comprised the $1154{ }^{14} \mathrm{C}$ measurements from the 3 laboratories, which together with those measured at Groningen and Yale, were used to develop a comprehensive calibration curve and tables (Klein et al. 1982).

Irish and European oaks were being used by this time to establish progressively longer tree-ring chronologies, and independent ${ }^{14} \mathrm{C}$ determinations were already underway by the late 1970 s. Eventually, the European oak chronologies (extended even further with older European pine chronologies) became the backbone of the currently accepted ${ }^{14} \mathrm{C}$ calibration (Friedrich et al. 2004), which contains no bristlecone ${ }^{14} \mathrm{C}$ results (Reimer et al. 2004). However, the use of wiggle-matching with the bristlecone ${ }^{14} \mathrm{C}$ record helped link together several floating (undated) segments in the early European chronologies (Linick et al. 1985; Damon 1987).

\section{RADIOCARBON-RELATED TREE PHYSIOLOGY AND SAMPLE PRETREATMENT}

In their early work, Arnold and Libby (1949) noted that wood from the interior of the giant sequoia sample had a ${ }^{14} \mathrm{C}$ date largely consistent with its dendrodates. They interpreted this as a demonstration that no metabolic processes in the tree, such as sap movement, result in the exchange or reequilibration of more modern ${ }^{14} \mathrm{C}$ with that laid down in these early rings. As it turns out, dendrodated wood from LTRR was particularly key in early studies testing mobility of carbon in tree rings.

Long et al. (1979) realized that the improvement of analytical precision and accuracy of ${ }^{14} \mathrm{C}$ measurements might be limited by the extent to which the wood compounds in a ring are exclusively formed in the year in which they reside, and if mobility is possible, the type of chemical pretreatment that could isolate the non-mobile chemical fractions. To that end, bristlecone pine tree rings from Inyo National Forest in California, dendrodated by their coauthor Ferguson, were prepared by several methods to observe differences in ${ }^{14} \mathrm{C}$ activity from $\mathrm{AD} 1860$ through the tremendous artificial production of excess ${ }^{14} \mathrm{C}$ during nuclear bomb testing, which peaked in the early 1960s. They found evidence that mobile extractives carried the bomb pulse to rings $100 \mathrm{yr}$ older than the pulse, and that minimally, solvent extraction should be performed on tree-ring samples to remove these constituents and significantly improve measurements. As a result of these findings, high-precision dating by the Arizona conventional ${ }^{14} \mathrm{C}$ laboratory eventually employed routine extraction of cellulose for analysis (Linick et al. 1986).

Ingrid Olsson (1980) obtained bristlecone pine samples from Ferguson (same tree as that used in the Long et al. 1979 study) to determine the chemical composition of wood in the heartwood (AD 18351955 ) and the sapwood (AD 1910-1930), especially with respect to extractives, and to study the effects of pretreatment. The extractives were found to be very mobile, carrying a much higher (i.e. 
younger) ${ }^{14} \mathrm{C}$ content into the rings being analyzed. However, organic solvent extraction or several pretreatments with sodium hydroxide were effective in removing this mobile component from the wood.

\section{A PRIMARY TREE-RING RADIOCARBON REFERENCE STANDARD}

Under an initiative in 1970 spearheaded by Henry Polach of Australian National University, a reliably dated primary wood standard was sought for distribution to ${ }^{14} \mathrm{C}$ laboratories. The ${ }^{14} \mathrm{C}$ community requested that LTRR prepare this standard from a single tree and that it contain the years 18461955 (Bannister and Damon 1972). The primary wood standard was to be used for the initial calibration of a new secondary standard (sucrose) to replace oxalic acid (oxalic acid I) whose supplies were becoming depleted, so enough material was to be prepared to supply 20 laboratories with $40 \mathrm{~g}$ of acid-alkali-acid pretreated wood. Wood from the Hitchcock Douglas-fir tree from the Santa Catalina Mts near Tucson, Arizona, was enlisted in 1971 for the project under the auspices of Bannister. This exceptional tree had blown down during a winter storm following the 1951 growing season, and many large cross-sections had been obtained by Schulman in 1952 for LTRR dendrochronological work. The chemical pretreatment took place under the supervision of Paul Damon and Austin Long of the Laboratory of Isotope Geochemistry in the Department of Geosciences at the University of Arizona. The interlaboratory calibration was undertaken (Polach 1979), and ultimately the sucrose became an important secondary standard (ANU sucrose), although a new oxalic standard (oxalic acid II) was also subsequently developed.

\section{CONCLUSIONS}

The Laboratory of Tree-Ring Research has contributed samples almost from the inception of the field of ${ }^{14} \mathrm{C}$ science. The capability of LTRR to provide wood samples whose dates are exactly known (rings are dated to the year) is the common thread in LTRR's contributions, including key landmark events in the ${ }^{14} \mathrm{C}$ enterprise such as the realization that natural production of ${ }^{14} \mathrm{C}$ is variable and the consequent need for calibration of the ${ }^{14} \mathrm{C}$ timescale.

In a supreme cosmic irony, Andrew E Douglass was attempting to reconstruct activity of the sun (sunspots) with the growth pattern of tree rings (Douglass 1927) several decades before he founded the LTRR. The results of his efforts were far from conclusive after more than 5 decades of research, but the advent of ${ }^{14} \mathrm{C}$ measurements in tree rings opened the door for many new solar studies in which solar activity (solar wind) influence on cosmic-ray flux appears to contribute to the amount of ${ }^{14} \mathrm{C}$ formation in the upper atmosphere (Damon et al. 1978; Stuiver and Quay 1980; Stuiver and Braziunas 1993). In fact, annual ring series from a ponderosa pine collected in the Santa Catalina Mts near Tucson (known as the "Radio Ridge" tree) had been used by Damon et al. (1973) to determine the magnitude of the $11-\mathrm{yr}$ (solar) cycle in ${ }^{14} \mathrm{C}$ production. As it turned out, Douglass, although still very active in the 1950s and early 1960s while in his 80 s and 90s, apparently had little role in the development of these ${ }^{14} \mathrm{C}$ tree-ring initiatives (other than personally dendrodating many of the pieces of wood contributed by LTRR) or in appraising the bounty of tantalizing geophysical (and astrophysical) information that ${ }^{14} \mathrm{C}$ calibration was gradually delivering (e.g. Damon and Sonett 1991; Damon and Peristykh 2000).

Since the 1980s, LTRR has continued to supply dendrodated wood samples for exploration of historical ${ }^{14} \mathrm{C}$ production. This has largely been for the projects of the late Paul Damon, particularly single rings or paired rings to obtain high-resolution records of ${ }^{14} \mathrm{C}$ activity from the last millennium (Damon et al. 1998, 1999). The recently rejuvenated and systematic effort commencing around 
AD 2000 to extend the bristlecone chronology (Hallman et al. 2006) may ultimately contribute more samples for future ${ }^{14} \mathrm{C}$ efforts, but both fields are likely to benefit from their interactions (Figure 6).

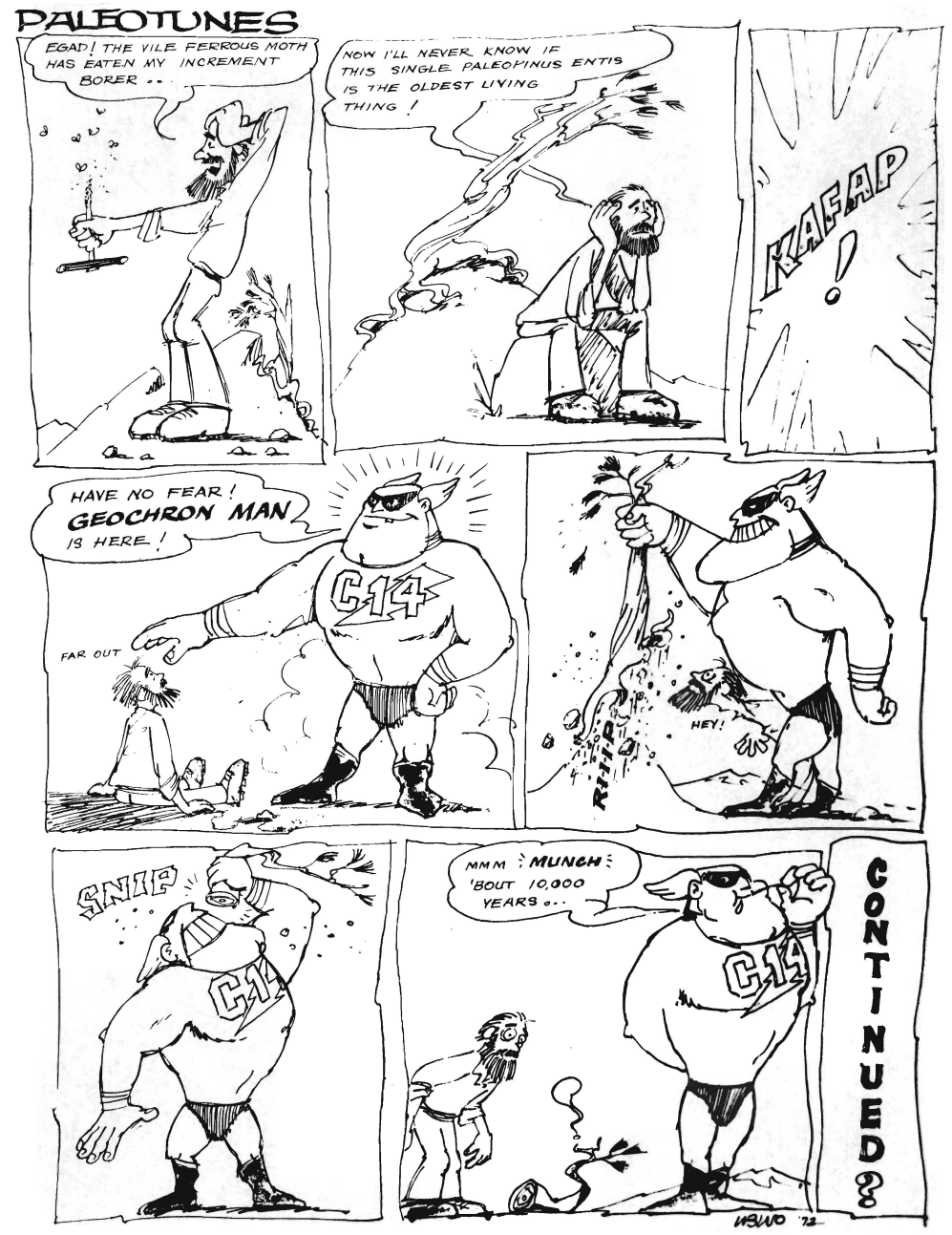

Figure 6 Cartoon depicting LTRR dendrochronologist C Wesley Ferguson being assisted by "Geochron Man" to date an ancient bristlecone pine-like tree. Although Geochron Man would have had to take large-mass samples to obtain conventional ${ }^{14} \mathrm{C}$ dates in 1972 when this cartoon was penned, of course today Geochron Man would need only a sliver of wood for accelerator mass spectrometry (AMS) dating [by kind permission of the artist, Wallace B Woolfenden].

\section{ACKNOWLEDGMENTS}

We thank Rex Adams, Christine Hallman, and Martin Munro for helping procure some of the images in the figures. Wally Woolfenden very generously provided his magnificent and pertinent cartoons used for two of the figures. Tom Harlan updated us on the most recent progress in development of the bristlecone pine chronology. An earlier version of the manuscript was very kindly read by Jeff Dean, Vance Haynes, Austin Long, and Minze Stuiver, and their comments are greatly appreciated. Reviewers Steve Nash and Mike Baillie provided helpful comments on the final draft. 


\section{REFERENCES}

Arnold JR, Libby WF. 1949. Age determinations by radiocarbon content: checks with samples of known age. Science 110(2869):678-80.

Arnold JR, Libby WF. 1951. Radiocarbon dates. Science 113(2927):111-20.

Bannister B, Damon PE. 1972. A dendrochronologically-derived primary standard for radiocarbon dating. In: Proceedings of the 8th International Conference on Radiocarbon Dating. Wellington, New Zealand, October 1972. p H81-H89.

Brannon HR, Daughtry AC, Perry D, Whitaker WW, Williams M. 1957. Radiocarbon evidence on the dilution of atmospheric and oceanic carbon by carbon from fossil fuels. EOS, Transactions, American Geophysical Union 38:643-50.

Cain WF, Suess HE. 1976. Carbon 14 in tree rings. Journal of Geophysical Research 81(21):3688-94.

Damon PE. 1987. The history of the calibration of radiocarbon dates by dendrochronology. In: Aurenche $\mathrm{O}$, Evan J, Hours P, editors. Chronologies in the Near East. BAR International Series 379. Oxford: Archaeopress. p 61-104.

Damon PE, Peristykh AN. 2000. Radiocarbon calibration and application to geophysics, solar physics, and astrophysics. Radiocarbon 42(1):137-50.

Damon PE, Sonett CP. 1991. Solar and terrestrial components of the atmospheric ${ }^{14} \mathrm{C}$ variation spectrum. In: Sonett CP, Giampapa MS, Matthews MS, editors. The Sun in Time. Tucson, Arizona, USA: University of Arizona Press. p 360-88.

Damon PE, Long A, Wallick EI. 1973. On the magnitude of the 11-year radiocarbon cycle. Earth and Planetary Science Letters 20(3):300-6.

Damon PE, Lerman JC, Long A. 1978. Temporal fluctuations of atmospheric ${ }^{14} \mathrm{C}$ : causal factors and implications. Annual Review of Earth and Planetary Sciences 6:457-94.

Damon PE, Lerman JC, Long A, Bannister B, Klein J, Linick TW. 1980. Report on the workshop on the calibration of the radiocarbon dating time scale. Radiocarbon 22(3):947-9.

Damon PE, Eastoe CJ, Hughes MK, Kalin RM, Long A, Peristykh AN. 1998. Secular variation in $\Delta^{14} \mathrm{C}$ during the Medieval Solar Maximum: a progress report. $R a$ diocarbon 40(1):343-50.

Damon PE, Eastoe CJ, Mikheeva IB. 1999. The Maunder Minumum: an interlaboratory comparison of $\Delta^{14} \mathrm{C}$ from AD 1688 to AD 1710. Radiocarbon 41(1):4750.

de Vries H. 1958. Variation in concentration of radiocarbon with time and location on earth. Proceedings of The Koninklijke Nederlandse Akademie Van Wetenschappen Series B 61:94-102.

de Vries H. 1959. Measurement and use of natural radiocarbon. In: Abelson PH, editor. Researches in Geochemistry. New York: John Wiley \& Sons. p 169-89.
Dorn TF, Fairhall AW, Schell WR, Takashima Y. 1962. Radiocarbon dating at the University of Washington. Radiocarbon 4:1-12.

Douglass AE. 1927. Solar records in tree growth. Science 65(1679):220-1.

Douglass AE. 1929. The secret of the Southwest solved by talkative tree rings. National Geographic Magazine 56(6):736-70.

Ferguson CW. 1968. Bristlecone pine: science and esthetics. A 7100-year tree-ring chronology aids scientists; old trees draw visitors to California mountains. Science 159(3817):839-46.

Ferguson CW. 1970a. Bristlecone pine chronology and calibration of the radiocarbon time scale. In: Smith JHG, Worrall J, editors. Tree-ring analysis with special reference to northwest America. The University of British Columbia Faculty of Forestry Bulletin 7:8891.

Ferguson CW. 1970b. Dendrochronology of bristlecone pine, Pinus aristata: establishment of a 7484-year chronology in the White Mountains of eastern-central California, U.S.A. In: Olsson IU, editor. Radiocarbon Variations and Absolute Chronology. New York: John Wiley. p 237-59.

Ferguson CW, Graybill DA. 1983. Dendrochronology of bristlecone pine: a progress report. Radiocarbon 25(2):287-8.

Ferguson CW, Huber B, Suess HE. 1966. Determination of the age of Swiss lake dwellings as an example of dendrochronologically-calibrated radiocarbon dating. Zeitschrift fur Naturforschung, Teil A:1173-7.

Ferguson CW, Lawn B, Michael HN. 1985. Prospects for the extension of the bristlecone pine chronology: radiocarbon analysis of H-84-1. Meteoritics 20(2):41521.

Friedrich M, Remmele S, Kromer B, Hofmann J, Spurk M, Kaiser KF, Orcel C, Küppers M. 2004. The 12,460year Hohenheim oak and pine tree-ring chronology from Central Europe-a unique annual record for radiocarbon calibration and paleoenvironment reconstructions. Radiocarbon 46(3):1111-22.

Glock WS, Agerter S. 1963. Anomalous patterns in tree rings. Endeavor 22:9-13.

Hallman C, Harlan T, Arnott H. 2006. Lost and found: the bristlecone pine collection. Tree-Ring Research 62(1): 25-9.

Klein J, Lerman JC, Damon PE, Ralph EK. 1982. Calibration of radiocarbon dates: tables based on consensus data of the Workshop on Calibrating the Radiocarbon Time Scale. Radiocarbon 24(2):103-50.

LaMarche Jr VC, Harlan TP. 1973. Accuracy of tree ring dating of bristlecone pine for calibration of the radiocarbon time scale. Journal of Geophysical Research 78(36):8849-58.

Lerman JC, Mook WG, Vogel JC. 1970. C14 in tree rings from different localities. In: Olsson IU, editor. Radio- 
carbon Variations and Absolute Chronology. New York: John Wiley. p 275-300.

Libby WF. 1961. Radiocarbon dating. Science 133(3453):621-9.

Libby WF. 1963. Accuracy of radiocarbon dates. Science 140(3564):278-80.

Libby WF. 1967. History of radiocarbon dating. In: $R a-$ dio-active Dating and Methods of Low-Level Counting. Vienna: IAEA STI/PUB/152. p 3-25.

Linick TW, Suess HE, Becker B. 1985. La Jolla measurements of radiocarbon in south German oak tree-ring chronologies. Radiocarbon 27(1):20-32.

Linick TW, Long A, Damon PE, Ferguson CW. 1986. High-precision radiocarbon dating of bristlecone pine from 6554 to 5350 BC. Radiocarbon 28(2B):943-53.

Long A, Arnold DL, Damon PE, Lerman JC, Wilson AT. 1979. Radial translocation of carbon in bristlecone pine. In: Berger R, Suess HE, editors. Radiocarbon Dating, Proceedings of the Ninth International Conference on Radiocarbon Dating, Los Angeles and La Jolla, 1976. Berkeley: University of California Press. p 532-7.

Marlowe G. 1999. Year one: radiocarbon dating and American archaeology, 1947-48. American Antiquity 64(1):9-32.

McGraw DJ. 2007. Edmund Schulman and the "Living Ruins.” Bishop, California, USA: Community Printing and Publishing. $161 \mathrm{p}$.

Olsson IU. $1980 .{ }^{14} \mathrm{C}$ in extractives from wood. Radiocarbon 22(2):515-24.

Polach HA. 1979. Correlation of ${ }^{14} \mathrm{C}$ activity of NBS oxalic acid with Arizona 1850 wood and ANU sucrose standards. In: Berger R, Suess HE, editors. Radiocarbon Dating, Proceedings of the Ninth International Conference on Radiocarbon Dating, Los Angeles and La Jolla, 1976. Berkeley: University of California Press. p 115-24.

Reimer PJ, Baillie MGL, Bard E, Bayliss A, Beck JW,
Bertrand CJH, Blackwell PG, Buck CE, Burr GS, Cutler KB, Damon PE, Edwards RL, Fairbanks RG, Friedrich M, Guilderson TP, Hogg AG, Hughen KA, Kromer B, McCormac G, Manning S, Bronk Ramsey C, Reimer RW, Remmele S, Southon JR, Stuiver M, Talamo S, Taylor FW, van der Plicht J, Weyhenmeyer CE. 2004. IntCal04 terrestrial radiocarbon age calibration, 0-26 cal kyr BP. Radiocarbon 46(3):1029-58.

Schulman E. 1954. Longevity under adversity in conifers. Science 119(3901):396-9.

Schulman E. 1956. Dendroclimatic Changes in Semiarid America. Tucson, Arizona, USA: University of Arizona Press. $142 \mathrm{p}$.

Schulman E. 1958. Bristlecone pine, oldest known living thing. National Geographic Magazine 113(3):354-72.

Stuiver M. 1961. Variations in radiocarbon concentration and sunspot activity. Journal of Geophysical Research 66(1):273-6.

Stuiver M. 1965. Carbon-14 content of 18th- and 19thcentury wood: variations correlated with sunspot activity. Science 149(3683):533-4.

Stuiver M, Braziunas TF. 1993. Sun, ocean, climate and atmospheric ${ }^{14} \mathrm{CO}_{2}$ : an evaluation of causal and spectral relationships. The Holocene 3(4):289-305.

Stuiver M, Quay PD. 1980. Changes in atmospheric carbon-14 attributed to a variable sun. Science 207(4426):11-9.

Suess HE. 1955. Radiocarbon concentration in modern wood. Science 122(3166):415-7.

Suess HE. 1965. Secular variations of the cosmic-rayproduced carbon 14 in the atmosphere and their interpretations. Journal of Geophysical Research 70(23): 5937-52.

Taylor RE. 1987. Radiocarbon Dating: An Archaeological Perspective. New York: Academic Press. 212 p.

Whitaker WW, Valastro Jr S, Williams M. 1959. The climatic factor in the radiocarbon content of woods. Journal of Geophysical Research 64(8):1023-9. 